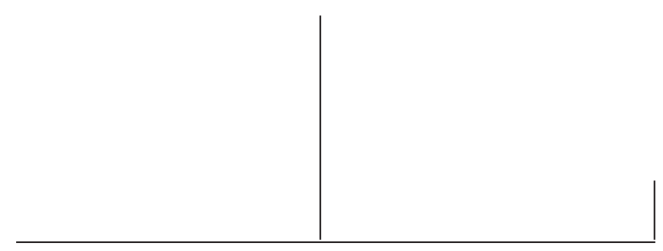

Rev. Latinoam. Psicopat. Fund., X, 2, 203-218

\title{
A política do erotismo na maturidade feminina: um estudo sobre as relações entre os estados hipocondríacos e melancólicos
}

\author{
Regina Maria Guisard Gromann
}

Este artigo enfoca as relações entre estados hipocondríacos e melancólicos presentes na passagem da maturidade feminina, isto é, no período do climatério e da menopausa, atravessado pela perda radical da capacidade biológica da procriação. Salienta-se o pathos feminino nesta etapa e a necessidade da mulher estabelecer uma nova política erótica que surge do seu corpo em transição, por meio da reedição préedípica e edípica vivida a partir da regressão e da transferência no processo analítico.

Palavras-chave: Psicanálise, hipocondria, melancolia, erotismo, menopausa 


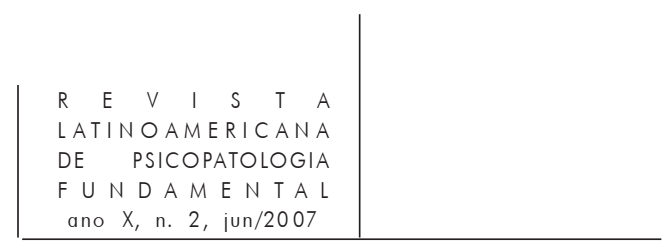

Uma noite, chegou à sua alma o desejo de moldar uma imagem d'O Prazer que nos habita um só momento. E lançou-se ao mundo para procurar bronze. Mas todo bronze da terra tinha desaparecido; em parte nenhuma deste mundo existia metal desse que pudesse ser encontrado. A não ser o que cobria a imagem d'O lamento que dura para sempre. Na verdade tinha ele mesmo, com suas próprias mãos, criado e deposto esta imagem no túmulo da única coisa que alguma vez amara na vida. Na sepultura daquilo que antes de morrer ele mais amara, colocou ele esta imagem do seu criar, para que pudesse servir como um sinal do amor do homem que durará para sempre. E em todo o mundo não havia outro bronze exceto o bronze desta imagem. Ele pegou na imagem que tinha esculpido e colocou-a numa grande fornalha, entregando-a ao fogo. E a partir do bronze da imagem d'O lamento que dura para sempre criou uma imagem d'O prazer que nos habita um só momento.

Wilde, "O autista|", 2002

\section{Preâmbulo}

O climatério e a menopausa tendem a ser abordados pela medicina atual como um momento "natural", isto é, visto somente pelo âmbito biológico, atribuindo aos seus sintomas algo incômodo, desagradável, incentivando a mulher a suprimi-los. Poucas publicações dão destaque às questões emocionais vigentes nesse período, reduzindo essa fase a alterações hormonais, sem que estas possam estar vinculadas a mudanças ocasionadas por uma complexa rede somatopsíquica, sendo, portanto, necessária uma abertura tanto para se pensar a crise quanto para favorecer um espaço para a mulher narrar suas vivências. Se, por um lado, o avanço da pesquisa farmacológica, acena com um maior conhecimento a respeito do funcionamento hormonal nessa etapa da vida feminina, por outro, a maneira de usar este conhecimento tende a retirar do cenário essas manifestações como sendo algo desprovido de relevância. A questão a ser delimitada é: por que esses sintomas não podem contar nada à respeito da 


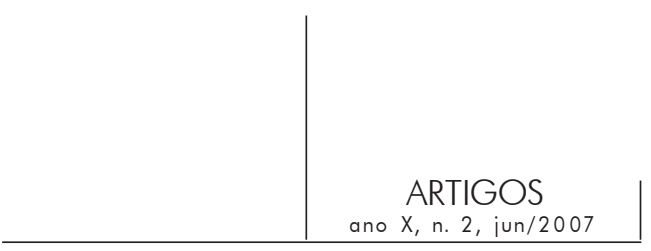

dinâmica da mulher nessa ocasião? Por que o mutismo imposto aos órgãos? Tanto a tensão pré-menstrual quanto os sintomas do climatério, os quais diferem em significação, são vistos como manifestações a serem erradicadas do discurso feminino. Tanto que algumas delas ao chegarem à clínica não vêem qualquer referência entre a menopausa, os seus sintomas e os conflitos vividos: "São a ação dos hormônios e pronto." Nada mais a pesquisar, nada mais a dizer. Contudo, isto não inviabiliza o uso da terapia de reposição hormonal, tornando-se, em alguns casos, relevante. Deste modo, até para a mulher poder decidir por seu uso precisará empreender um contato consigo, com seus ciclos e funcionamentos, dando-lhe expressão e narrativa. Algumas mulheres se servem dessa reposição muito antes de se instalar os sintomas dessa etapa, ${ }^{1}$ como uma forma de evitar os sinais da continuidade do tempo, da ação cronológica, não havendo, assim, a oportunidade de um padecimento, no sentido páthico, que poderia levá-la a um saber e a um cuidado de si.

Algumas publicações trazem a mulher dissociada de seus ovários, como nos diz Campolim (2002) "Este livro trata do fim do compromisso das mulheres com a reprodução biológica da espécie, um processo que tem a ver com o tempo e com certa idade, sem dúvida, mas principalmente, com os ovários” (p. 8).

E mais adiante em sua exposição:

... discute-se ainda o fato de a menopausa prenunciar o envelhecimento e representar assim uma época emocionalmente marcante da vida das mulheres, que mexe com a vaidade. Mas essa é uma questão filosófica complexa que, de resto, também afeta os homens e foge ao âmbito deste livro. Diante da indiferença da natureza para com o ciclo inexorável da vida, ciclo que a cultura humana, historicamente, teima em desafiar, o que interessa aqui são as informações e recursos práticos à disposição das mulheres climatéricas. Vamos a elas. (p. 12)

O que podemos depreender deste texto? Já que a "natureza" é "inexorável", nos curvemos a ela. Sejamos naturais! E quanto à cultura humana? Um desafio inútil que não pode levar à transformação psíquica, nem tampouco ter algum sentido, portanto, voltemos à "prática”. O que interessa, então, é aquilo que é natural, fisiológico, destituído de significação. Assim, "uma época emocionalmente marcante da vida das mulheres" fica reduzida ao "que mexe com sua vaidade". Até mesmo diferenciar os homens das mulheres acaba sendo uma "questão filosófica". Ou seja, os aspectos psicológicos são extintos de sua pesquisa. ${ }^{2}$

1. Matéria "Tratamento precoce" publicada na "Folha Equilíbrio", suplemento da Folha de S. Paulo, em 16/2/2006.

2. Patrocinada pelo Laboratório Wyeth. 


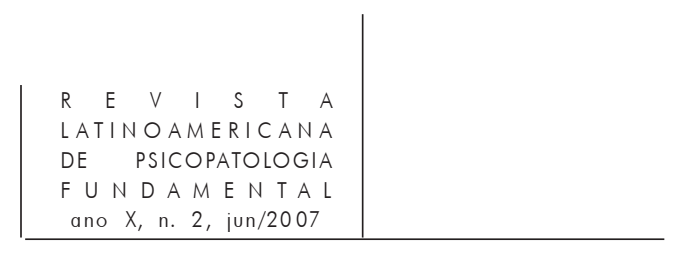

Será que estaríamos retornando a um período pré-freudiano no que concerne ao corpo da mulher, expressão sem narrativa, sem olhar, sem escuta?

Freud com os seus estudos sobre a histeria funda a psicanálise, inaugurando um olhar e uma escuta ao universo feminino. Sendo assim, os sintomas histéricos, bem como os quadros hipocondríacos e somáticos são manifestações que têm muito a dizer a esse respeito. É, portanto, este "desafio" que não pode cair por terra, pois é em meio à relação entre a natureza e a cultura que se move a libido feminina.

Partindo de uma reflexão clínica, pretendo iniciar um estudo dos sintomas hipocondríacos presentes no momento da menopausa, relacionando-os ao luto do corpo e à sua possível vizinhança com aspectos melancólicos. Proponho neste percurso evidenciar a relevância dos sintomas bem como do significado da preocupação hipocondríaca nesta etapa. Neste sentido, a hipocondria parece ser o paradigma da ruptura surgida no climatério. Esta afecção, juntamente com a histeria e algumas somatizações, pode surgir em caráter transitório, ao longo desse período, conforme as observações clínicas em realização nesta pesquisa.

\section{Do corpo da maternidade ao corpo da maturidade}

No limiar da perda da capacidade procriadora, a mulher se vê às voltas com um enigma envolvendo seu corpo: diminuição hormonal, aumento libidinal (Freud, 1912), um corpo estrangeiro se avizinhando com sintomas vasomotores e mudanças no ciclo menstrual fazendo dela uma estranha. O corpo, não obedecendo mais aos ciclos esperados, lança-a a um terreno desconhecido e angustiante, povoado por muitas fantasias. Acrescenta-se a este panorama a idéia de que enquanto a menarca simboliza para a jovem sua entrada no mundo da mulher-mãe acenando-lhe uma potência, no climatério vê-se diante dessa perda, tendo que ressignificar a equação que lhe é tão cara, ou seja, ser mulher $=$ ser mãe. Quando a menopausa se aproxima, rompe-se esta equação e a mulher necessita realizar um trabalho que aqui denomino de uma política, "arte de dirigir as relações entre os Estados" (Bueno, 1976), ${ }^{3}$ ou seja, uma nova posição a ser conquistada para se tornar mulher. Neste cenário o corpo feminino torna-se um corpo em transição. O climatério, por excelência, é o sinal do momento em que deixará de ser mãe, precisando inventar um novo corpo erótico que não seja o do corpo-mãe.

Este corpo em transição, trazendo mudanças somatopsíquicas, solicita da mulher sua percepção diante da ruptura e da crise que deve ser vivida e

3. Uma das definições de política. 


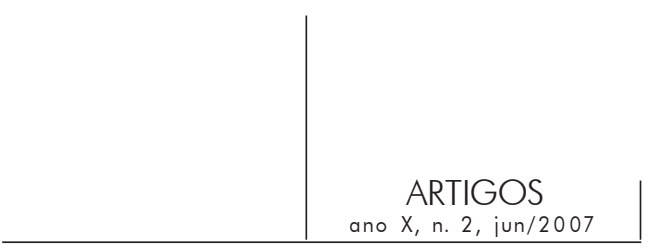

ultrapassada, necessitando de movimentos exogâmicos, isto é, novas ligações, uma saída do incesto para o encontro de sua feminilidade.

Por meio da clínica pude observar o processo das mulheres diante deste tempo, acercando-me da função das cirurgias reparadoras, do apagamento das marcas do corpo-mãe e das relíquias deixadas como rastros dessa etapa, configurando um movimento de passagem. Destarte, perder o corpo da maternidade significa transformar sua identidade primordial e renunciar, por meio do luto, à ancoragem biológica a que estavam submetidas, indo ao encontro de novas políticas eróticas.

Nesta parte do trabalho serão examinados aspectos ligados ao luto desse corpo em transição, mencionando o processo empreendido por uma paciente neste trajeto. Para tanto, as observações clínicas serão articuladas às contribuições teóricas de Ferenczi, Abraham e Torok (1995), mais especificamente na discriminação que realizam dos conceitos de incorporação e introjeção do objeto primordial, salientando os aspectos orais e anais preponderantes nestes mecanismos. Nesta medida, a imagem surgida a partir do funcionamento primitivo na menina-mulher é a de um "canibal amoroso", no que concerne à identificação com a mãe, figura dominante no Édipo feminino e na sua constituição identitária.

\section{Carmem - Um caso em que hipocondria e melancolia se encontram}

As teorias sexuais infantis estão em plena ação na hipocondria.

Fédida, 1995

Carmen, uma mulher de meia-idade, atendida há tempos, apresentava diversos sintomas hipocondríacos envolvendo o trato gastrointestinal e o aparelho reprodutor, referindo-se também a um diabetes, em função de uma sobrecarga de peso corporal. Sua situação familiar sempre fora difícil e pantanosa, trazendo um cenário de repetições de fracasso e imobilizações diante da vida, imersa numa intensa atmosfera melancólica que resultavam em oscilações que variavam do sentimento de impotência à onipotência. Sentia-se muito ligada aos seus, demonstrando pouca autonomia para tomar algumas decisões. A partir de uma intensa batalha em que se mesclavam culpa e temor, resolveu envolver-se em seu trabalho, aumentando seus ganhos. Durante muito tempo sua fantasia era de penúria e de abandono. Sua relação com a mãe apresentou-se muito conturbada, queixando-se freqüentemente de se sentir excluída de sua convivência, em detrimento de seus afazeres. Seus relatos traziam uma grande luta em torno dos pólos submissão e fúria. Temia muito seus afetos, atribuindo a eles um valor 


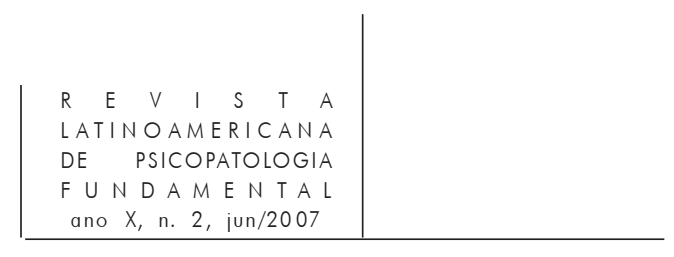

onipotente, reprimindo-os, o que a fazia oscilar ainda mais em termos de humor. Sentia-se injustiçada. No entanto, rebaixava-se a todo momento, evitando situações em que se confrontasse com autoridades ou onde ocupasse um lugar profissional de destaque, embora trabalhasse para isso. As cenas trazidas tanto de sua família de origem, quanto da atual, referiam-se a explorações financeiras, perdas de bens materiais, temendo ficar cada vez mais empobrecida. Perdeu o pai ainda menina e durante a doença que o acometera e que se arrastara por um longo tempo, ficava ao seu lado velando por sua recuperação. Quando veio a falecer, sentia-se incapaz e negligente com seus cuidados, o que determinou seus afetos ambivalentes: se, por um lado, cansava-se de vê-lo irremediavelmente doente, esperando um fim para seu tormento, por outro, nutria a esperança de poder salválo, parecendo ter sempre se ocupado com um pai morto.

No entanto, apesar desse panorama, Carmem se debatia com as dualidades que surgiam em seu processo: amor/ódio; paralisação/movimento; passividade/ atividade; submissão/ira.

Os sintomas hipocondríacos e somáticos surgiram nos momentos quando, no tratamento, tangenciaram o atravessamento da reedição pré-edípica e edípica, desencadeada pela regressão. Assim acordava à noite sentindo uma constrição na garganta; numa outra ocasião, trouxe a suspeita de estar com câncer no intestino. Sentia sua barriga crescer demasiadamente levando-a freqüentemente ao Pronto Socorro, tirando várias radiografias, por achar que havia algum tumor se desenvolvendo em seu interior. Suas fantasias pareciam se referir a algo em seu ventre prestes a destruí-la. Os sonhos narrados, durante um período de seu processo referiam-se a figuras femininas mortas, onde só ela percebia que se mexiam; isto é, eram, aos seus olhos, mortas-vivas. Havia também neles transações financeiras em que ela se via "pagando" para sair de sua posição passiva, bem como situações em que tinha que escolher entre imagens coloridas em contraste com outras escuras, mencionando em suas associações que sempre desejara eleger as primeiras, embora sempre lhe fossem destinadas as segundas, ou seja, sobressair de sua posição de morta. Essas narrativas oníricas vêm após várias ocorrências em que manifestava ódio e fúria ligados à figura materna, trazendo à tona a sua tentativa de elaboração a respeito de outra dualidade presente, estar morta/viva: tanto a morte do pai, quanto o "fingir-se de morta" e de sua atitude passiva diante da vida. Numa dada ocasião relata que ao sair de casa deixou com sua mãe todos os seus pertences como um "pagamento", uma alforria pelo seu afastamento dela, tendo que se distanciar para que pudesse viver sua vida, trazendo aspectos de rivalidade, tentativas de invasão e depreciação de sua posição feminina, tentando em contrapartida, resgatar sua relação com ela.

O cenário transferencial era predominantemente primitivo e transbordante: sua fala prolixa e com fortes cores afetivas, expressavam o caráter de sua 


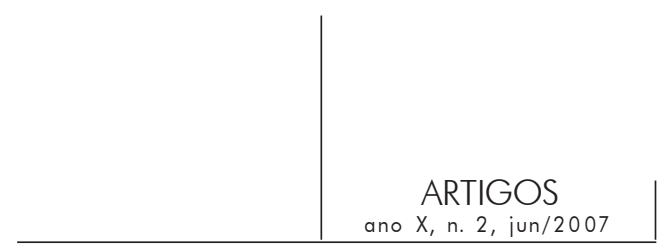

ambivalência emocional. Trazia histórias infantis de muita violência e o afeto recorrente era o da fúria silenciosa que permeou suas relações com as imagos parentais, principalmente com a imago materna. Algo nela ainda habitava este cenário, embora buscasse se indagar freqüentemente, diante desta atmosfera. Seus sintomas somáticos pareciam ter uma prevalência hipocondríaca, de cunho persecutório, mencionando sentir seu corpo "mudar" com freqüência o que a deixava muito angustiada, imaginando-se doente.

O embate de Carmem no processo analítico situava-se entre as fantasias infantis de incorporação (oral/anal) relacionadas ao ter filhos do pai, representada por ocorrências de violação, sentindo culpa e desespero por sentir prazer com elas, versus a tentativa de introjeção de um objeto que a resgatasse desse lugar oculto em que o desejo pudesse ser mediado, um objeto-mãe cuidador que refletisse seu crescimento como mulher. Aqui temos os pólos mágico/trabalho; interdição/ transgressão no seu trajeto edípico em seus sonhos: nestes surgem a idéia de que precisava sair dos pólos de submissão/fúria, passividade/atividade para se tornar mulher, ou seja, aspectos que necessitavam integrar-se no ego para que ganhassem em expansão. Deixar de se "fingir de morta", significava resgatar sua sexualidade, seu erotismo renegado por ser proibido e por ter sido incorporado com volúpia. Para isto era necessário haver um pagamento, existindo, assim, um ônus que até então resistia em perceber. $\mathrm{O}$ pagamento parecia ser a referência ao custo de sua análise. Isto é, para crescer seria necessário pagar com o ônus da interdição. Só assim poderia transgredir como mulher, cuidar de seu "colapso", "ir atrás do prejuízo", segundo ela.

Abraham e Torok (1995) mencionam

... a introjeção, segundo Ferenczi, reserva ao objeto - e ao analista, no caso - um papel de mediador para o inconsciente. Operando num vai-e-vem "entre o narcísico e o objetal", entre o auto e o hetero-erotismo, ela transforma as incitações pulsionais em desejos e fantasias de desejos e, conseqüentemente, torna-os aptos a receber um nome e cidadania e a se abrir no jogo objetal. (p. 222)

Este processo denomino de política do erotismo. Na maturidade feminina, a mulher, ao transgredir a sua função de reprodutora da espécie, passa a ter que se incluir num novo lugar na pólis, numa nova posição erótica, e, para tanto, necessita realizar um trabalho psíquico que lhe outorgue uma abertura ao "jogo objetal". Assim sendo, esta conquista, este lugar, demanda um trabalho de atravessamento em que realiza uma "troca de moeda": o sintoma, pelo preço a pagar pelo desejo. Assim, transforma "incitações pulsionais em desejos e fantasias de desejo", e desta forma ganha "um nome e cidadania" nesta abertura.

Incorporação e introjeção apresentam-se como mecanismos diferentes, embora inicialmente, num nível muito arcaico, se confundam. Enquanto o primeiro 


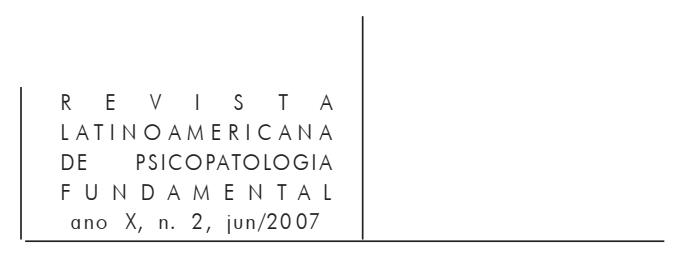

refere-se a uma "fantasia de ingestão" a uma "magia oculta para recuperar o objetoprazer", o segundo diz respeito a um processo de "alargamento do ego". "Descrevi a introjeção como um mecanismo que permite estender ao mundo exterior os interesses primitivamente auto-eróticos, incluindo os objetos do mundo exterior no Ego" (ibid., p. 221). Este mecanismo permite compreender três pontos: "Extensão dos interesses auto-eróticos; alargamento do ego pela eliminação dos recalcamentos e inclusão do objeto no Ego e, conseqüentemente, 'objetalização' do auto-erotismo primitivo" (ibid.). O mecanismo da introjeção, embora esteja num nível arcaico confundido com o da incorporação, necessita vincular-se ao princípio de realidade, por um alargamento que é mediado. Opera-se, assim, uma política de expansão para a alocação do desejo, por meio da objetalização do autoerotismo, uma inclusão do objeto no ego. "Semelhante à transferência (seu modo de ação no tratamento), ela se define como o processo de inclusão - a propósito de um comércio objetal - do inconsciente no ego" (p. 222).

E mais adiante "É que precisamente, a aspiração da introjeção não é da ordem da compensação, mas da ordem do crescimento: ela busca introduzir no ego, alargando-o e enriquecendo-o, a libido inconsciente, anônima ou recalcada" (ibid.). Desse modo, é um mecanismo que inaugura uma política transgressiva, um trabalho de realocação de objetos de desejos. No entanto, diante da "compensação do prazer perdido e da introjeção ausente, realizar-se-á a instância do objeto proibido no interior de si. É essa a incorporação propriamente dita". Esta pode operar "no modo da representação, do afeto ou de algum estado do corpo" (ibid.).

Ora, vemos aqui o estado do corpo hipocondríaco em Carmem, tão penoso a ela, retornando em momentos próximos aos relatos turbulentos de sua vida infantil. Se nos lembrarmos que Fédida (1995) menciona que a hipocondria é em sua essência a expressão das fantasias sexuais infantis, temos, neste caso, a revivescência hipocondríaca em Carmem como a expressão culposa de suas fantasias sexuais infantis ligadas a ter um filho do pai, reforçadas por atos abusivos, impossíveis de serem interditados e que custou a ela a impossibilidade de gerar filhos; isto é, este desejo vivido como volúpia não pôde ser mediado, mas vivido de forma crua e culposa, expressando-se por meio de somatizações. Esses acometimentos hipocondríacos poderiam ser, em última instância, uma "crise maníaca aberta" que necessitava ser escondida, uma "magia recuperadora" proibida. "Pois não esqueçamos que ela nasceu de um interdito que ela contorna, sem verdadeiramente transgredi-lo. Ela tem por objetivo, no final das contas, recuperar, num modo mágico e oculto, um objeto que, por qualquer razão, se furtou à sua missão: mediatizar a introjeção do desejo" (p. 223). A incorporação, neste sentido, se opera como um roubo. No caso de Carmem podemos ver a questão do dinheiro e da prevalência da miséria e das várias situações de colapso como sendo o empobrecimento a que ficou submetida pela culpa, pela falta da 


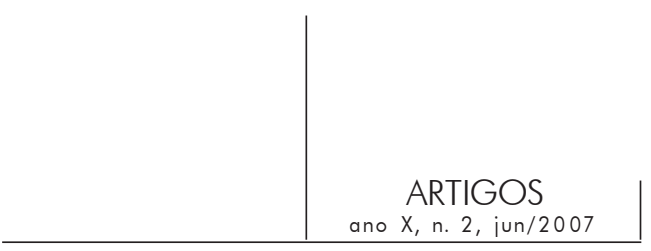

introjeção e pela sua contrapartida, a incorporação mágica, sendo o preço a pagar a pena pelo seu roubo incorporativo.

É importante ressaltar que neste caso, justamente na menopausa, quando a possibilidade de se tornar mãe biológica se extingue e quando os aspectos orais e anais são tão proeminentes, em virtude da regressão a aspectos pré-edípicos, a paciente menciona que pela primeira vez pudera tocar em aspectos tão profundos de sua vida, corroborando a idéia de que nesta etapa surge uma nova tentativa de elaboração. A hipótese é de que, após a ruptura vivida na menopausa, a mulher poderá entrar em contato mais íntimo consigo, sendo seus sintomas hipocondríacos uma via de conhecimento, buscando realizar um atravessamento edípico rumo a uma nova política.

\section{Um corpo em transição: a política da introjeção do desejo ou a incorporação mágica?}

Poderíamos, assim, nos indagar, aprofundando a pesquisa no pathos feminino no climatério, se este corpo em transição só poderia se constituir enquanto um corpo do desejo por meio da narrativa e da escuta clínica. Se considerarmos as várias incorporações mágicas a que as mulheres passam, desde problemas ligados a distúrbios da oralidade (dietas severas, medicações, cirurgias e outros dispositivos), até sintomas somáticos que surgem na região do ventre, estes, seriam a expressão de uma tentativa de processar aspectos ligados aos mecanismos da incorporação e da introjeção? Estaríamos então no terreno daquilo que Torok e Abraham denominam de "doença do luto"? Se há um corpo em transição, também poderíamos pensar num luto em transição, em que ocorreriam momentos maníacos e melancólicos sem se encontrarem definitivamente fixados? Como é, enfim, o processo de luto na menopausa? É possível fazer luto do corpomãe? E de que maneira é possível este corpo da volúpia tornar-se um corpo do desejo? Parece existir aí uma intersecção para reflexão entre aspectos superegóicos primitivos e um "alargamento do ego" (Ferenczi), que serão aprofundados em outra oportunidade.

\section{Um estudo do Édipo feminino e suas passagens: o destino feminino revisitado no climatério}

A crise feminina na maturidade, portanto, se oferece como uma oportunidade de se conhecer e se aprofundar os caminhos a respeito da constituição da 


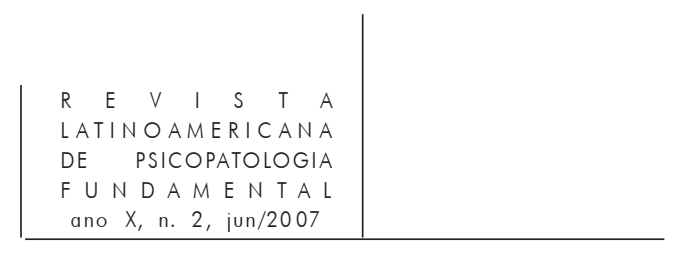

feminilidade, tendo o corpo como cenário desta crise. Desde o axioma freudiano de que é impossível compreender a mulher "a menos que valorizemos essa fase de sua vinculação pré-edipiana à mãe" (Freud, 1933), é imprescindível abranger este tema tendo em vista os aspectos psicopatológicos envolvidos nesta relação, mais propriamente aquilo que poderíamos denominar de uma psicopatologia somática. $\mathrm{O}$ pathos feminino na maturidade advém de uma convergência de fatores somáticos e que nos aludem a uma relação apaixonada e primitiva com a mãe, que parece nunca se esvanecer. A partir desta citação, André (1986), discutirá e aprofundará os aspectos ligados a esta afirmação, seguindo Freud que menciona sempre um mesmo enigma diante da identificação feminina “... a relação com o pai não faz realmente desaparecer, para a menina, a relação primária com a mãe. Ela só constitui um 'adiamento', uma 'prorrogação' desta, como ele o dirá em seu artigo sobre a sexualidade feminina" (p. 171).

No caso clínico narrado, vê-se surgir, nesta etapa, uma ambivalência amorosa e conflituosa relacionada à figura materna que se acirra, bem como com o próprio corpo mutante. Como num jogo de espelhos a mulher se estranha, alternando sentimentos de inferioridade com tentativas maníacas de sobrepor este afeto, muitas vezes ligados a um ressentimento diante do corpo perdido da juventude. Esta passagem melancólica está, pelo que parece, relacionada à travessia edípica feminina, ao que retorna desta, ou seja, àquilo que não recebeu da mãe. Os aspectos melancólicos poderiam estar relacionados à incorporação e à oralidade, ressurgindo desta maneira os aspectos identificatórios a serem reeditados. Ódio e amor são os afetos prementes, definindo, assim, certo canibalismo amoroso, configurando a qualidade desta relação. Desta forma, neste processo identificatório que ressurge da menina com a mãe poderia haver elementos hipocondríacos e melancólicos associados como condição de passagem para a constituição de uma nova imagem corporal.

André observa: "A mãe se apresenta para a menina, ao mesmo tempo como um objeto de amor (Um Outro) e como um pólo de identificação (um outro)" e " ... para a menina a identificação com a mãe parece ser a condição pela qual seria possível não mais amá-la - o que é absolutamente paradoxal" (p. 185). Os pólos atividade/passividade necessitam de uma elaboração, pois esta dialética "equivale a uma oscilação entre ser o objeto da mãe e tomar a mãe como objeto: é uma luta em torno do objeto, do lugar do objeto, onde vão se distribuir as posições subjetivas" (ibid.). Há, portanto, um intenso esforço nesse sentido sendo nesta passagem que se dá a crise feminina, o que não deixa de ser a premência da mulher realizar uma política, aqui no sentido da busca de um novo lugar.

A questão da incorporação refere-se à fantasia ambivalente de "engolir" a mãe, isto é, de possuir um objeto que poderá tanto ser benéfico, quanto o de danificar o interior de seu corpo, reativando fantasias hipocondríacas de destruição. 


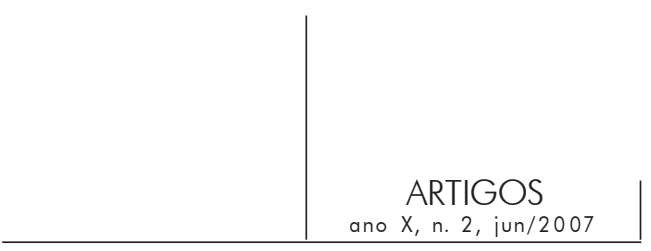

As apalpações e estranhamentos somáticos parecem se relacionar à fantasia de “onde está a mãe e o que está fazendo". A fantasia de devoração é por natureza de quem sobrevive a quem, e de controle. "Quer-se devorar a mãe pela qual se foi alimentado" e “... Esta relação primária com a mãe não é sob aspecto algum uma fusão ou comunhão: ao contrário, é uma luta ferrenha cujo objetivo, em última instância, é o de determinar quem vai devorar o outro” (p. 186).

Voltando ao nosso caso, Carmem traz a imagem de um pai morto, e que antes de morrer mostrava-se depauperado pela doença. Lembra-se dele como alguém ausente, por vezes relutante em estar em sua companhia, sentindo-o arredio e inacessível. Sua mãe, por sua vez, é descrita como uma mulher sofrendo de algumas fobias. Nas ocasiões em que manifestava as crises fóbicas, tinha, segundo ela, que se imobilizar até que a mãe se acalmasse, tendo que se "esquecer" dela mesma. Eram momentos penosos em que não podia expressar qualquer emoção, pois se assim ocorresse sua mãe punha-se a gritar, num intenso descontrole. Seu pai nunca se achava presente nessas ocasiões, e, desse modo, somente lhe restava a via de "fingir-se de morta", perante o desgoverno materno.

Diante da figura apagada do pai, tanto no que concerne à percepção de seus atributos femininos, seja enquanto fazendo par com a mãe, Carmem fica capturada neste espaço de imobilidade. Seu sonho parece ressaltar o caminho para um morto que se finge, num encontro consigo própria, com sua sexualidade fingidamente imóvel, que até então era paga pelo sintoma somático. Neste momento, reconhece existir um valor de troca, do sintoma para o desejo. Ou seja, ante a incorporação "roubada" versus a introjeção do desejo, necessita realizar uma operação de câmbio, a troca da moeda do sintoma incorporativo pelo da introjeção de seu desejo, passando pela interdição. Neste sentido, o custo da análise também surge com todas as demais repercussões: perceber sua situação, resgatar seus prejuízos financeiros, estancar as "hemorragias" das perdas de seus bens, representando as fissuras de seu ideal de eu. Na transferência, vê-se confrontada com a figura da analista tanto no que se refere aos aspectos maternos, de espelhamento de sua feminilidade, quanto da interdição, representados pelo "câmbio da moeda": do sintoma para o pagamento da análise.

Depois de um tempo conturbado, Carmem manifestou uma série de mudanças que se revelavam através de seu corpo mais magro; o desaparecimento, em seus relatos, de seus sintomas gastrointestinais, bem como os que se referiam à constrição laríngea e a toda gama de sintomas vasomotores que permearam durante um longo tempo o trabalho analítico.

Mencionava sentir-se diferente, mais introspectiva, à mercê de um contato mais íntimo consigo mesma. Em contrapartida, surpreendia-se com este movimento, de poder se colocar nesta posição, observando-se e tolerando mais a angústia, isto é, quando se percebia com espaços e vazios, o que antes lhe 


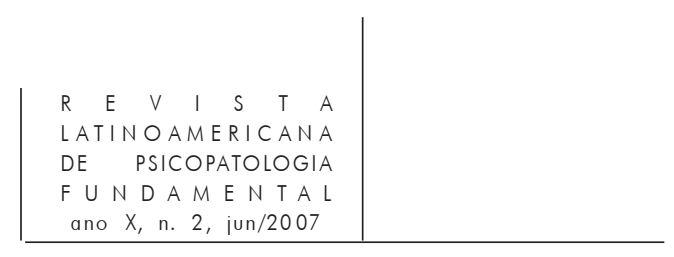

custava "comer desenfreadamente", motivo de sua anterior obesidade. Seu relato mostrou-se permeado por novas percepções: percebia seu emagrecimento como se estivesse se "desfazendo de antigas bagagens". Citava também outras alterações, como vertigens, pressão no peito, associada a náusea e vômitos. O médico, figura de realce na hipocondria, prescreveu-lhe exames que não diagnosticaram um quadro clínico preciso, deixando-a preocupada e pensativa, o que num momento posterior pôde ser associado a um "mareamento" e à angústia diante de novas situações de sua vida.

Seu corpo em transição atestava flutuações, indicando um rumo de mudança. Ao reconhecer um espaço interno, um oco, um "esvaziamento", estaria se encaminhando a uma "organização narcísica do vazio" e suas possíveis brotações próprias da depressividade? Esta condição não seria, em essência, o lugar do afloramento da feminilidade? Uma outra potência? Não existiria a qualidade de um espaço potencial que vez por outra abrigaria um broto? Espaço transitório de abrigo, diferenciando-se da posição fálica preenchida perenemente? Neste sentido, ao passar pelo estado depressivo, poderia fazer o luto do corpo - mãe?

Em suas associações posteriores trouxe lembranças de histórias escutadas na infância que se vinculavam a animais que machucavam e engoliam suas crias, mencionando que ficar muito perto da mãe, às vezes era perigoso. Estas lembranças a tomaram de surpresa e reflexão, observando a intensidade dos afetos que marcavam a relação mãe e filha. Por conseguinte, sair do alvo da mãe "perigosa" significava também, por projeção, rever os aspectos ambivalentes do "canibal amoroso"; a separação necessária que instaurou uma posição menos idealizada e infantil diante da figura materna. Parecia também sair da posição masoquista, de não mais ficar à mercê dos ataques maternos e familiares, que a imobilizaram, saindo do alvo de ser engolida e, nesta medida, mudando da posição oral e anal para a condição genital, descobrindo este espaço interno que pode fertilizar e criar novos brotos, dando-lhes a luz. Elaboração que a conduzia a uma mobilização psíquica.

O espaço potencial da feminilidade, o oco, o vazio, parece ser um lugar transitório e que em alguns momentos poderá abrigar o objeto melancólico, morto, mas também poderá ficar vazio para a criação.

\section{O valor do quadro hipocondríaco na crise feminina}

O conjunto dos mecanismos observáveis na constituição da hipocondria encontra-se assim compreendido sob dois grandes títulos, o do narcisismo e o do objeto perdido, ou seja, com esta dupla referência tocamos em uma 


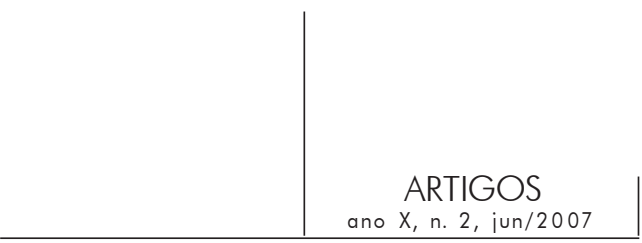

organização vizinha, a melancolia, colocando-se a questão sobre suas relações e posições. (Merot apud Fine, 1995, p. 75)

O que pudemos determinar nesta travessia é que os sintomas somáticos da clínica feminina podem levar a mulher a um relevante conhecimento de si e a respeito do trabalho de enlaçamento ao psíquico de seus ciclos (incluindo o ciclo da vida) e do funcionamento do próprio corpo, bem como dos afetos que afloram durante esta etapa, concernentes a etapas primitivas da evolução do psiquismo. Portanto, o eixo deste trabalho parece se situar no valor da manifestação hipocondríaca enquanto um conhecimento próprio advindo da ruptura somatopsíquica, e uma tentativa de reencontro com um corpo estranho e com suas delimitações.

No artigo "A história da hipocondria", Guedeney e Weisbrot (1995) realizam um interessante percurso deste quadro ao longo dos tempos, desde a medicina hipocrática, apresentando uma gama de definições. "A hipocondria foi introduzida como uma simples gastrite no séc. IV a.C. por Diocles de Caristo". Foi definida posteriormente por Hipócrates e Galiano como uma doença que reunia uma lesão visceral específica a um acometimento psíquico, caracterizado pela tristeza e pelo temor perene (p. 31).

A definição datada de 1781 é "afecção nervosa que antigamente se acreditava de origem abdominal e que deixa o doente angustiado com sua saúde" (p. 32). O texto menciona a íntima relação com a melancolia, presente nos estudos hipocráticos, sendo que no século XIX, se aproximará da neurastenia, da histeria e do delírio.

No entanto, como a hipocondria é vista atualmente?

Esta manifestação traz confluências relevantes para uma reflexão. Em primeiro lugar, a hipocondria sempre se refere a um médico, demanda uma escuta médica. Isto é, alguém que especulariza e ausculta um corpo, destacando a relevância da transferência. Fédida (1995) nos diz:

O hipocondríaco médico não é simplesmente aquele que revelaria um saber médico - sob determinados aspectos normalmente delirantes - que entra em concorrência com o saber do médico. Ele é este médico imaginário, em certo sentido, na origem do conceito metapsicológico da saúde e que saberia que o psíquico é o instrumento mais certo de autoscopia do órgão. Pois a linguagem de órgão merece, com efeito, ser completamente considerada. Enquanto o sonho, diz-nos Freud citando Aristóteles, tem a capacidade de conhecer e de nos fazer conhecer sob um modo "criptado" (porque mascarado) o estado constante de nossos órgãos, a hipocondria está promovida como uma teoria infantil do somático. (p. 136)

A pesquisa de um corpo em transição na maturidade feminina, não pode prescindir da abordagem das fantasias inerentes a esta passagem, relacionada à regressão, às teorias sexuais infantis acerca do próprio corpo e do corpo das 


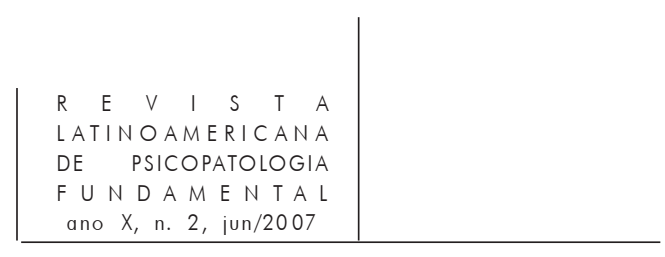

imagos parentais, bem como relacionando-se com a angústia que surge como afeto preponderante.

Em segundo lugar, a hipocondria refere-se à tentativa de delimitação de um corpo, suas fronteiras, constituindo um espaço dentro/fora, marcando o que Freud define como "eu corporal". A tentativa de, por meio da fantasia hipocondríaca, poder habitar um corpo.

Segundo Pragier (1995) "A clínica da hipocondria parece-nos poder ser utilizada para compreender melhor os processos que regem as flutuações dos limites entre o dentro e o fora" (p. 84). Menciona as noções de "limite do eu" (Freud, 1895) e de sentimento do eu (Federn) para justificar esta configuração.

Aisenstein (1995) argumenta a relevância da hipocondria enquanto um processo de articulação somatopsíquico.

... a hipocondria seria vista como processo, tentativa de ligação, trabalho psíquico, em suma, e sinal de alerta de um perigo na esfera narcísica. Será preciso supor um mínimo de investimento hipocondríaco do corpo necessário a qualquer organização psíquica. (p. 106)

Esta tentativa de ligação seria o modo, por excelência, de reconhecer um corpo e dar-lhe um estatuto pessoal, a partir de um trabalho de ligação, passando pela especularização, em primeira instância, pelo objeto materno, depois, pelo paterno e mais tarde pelo olhar amoroso do parceiro, que é revisitado na figura do médico e do analista, por meio da transferência; ou seja, é pelo trabalho psíquico e em última instância, da transferência, que o corpo e sua imagem se reconfiguram. Deste modo, o sintoma hipocondríaco traduz o imperativo da libidinização do corpo estranho.

No entanto, como pudemos observar através do caso clínico comentado, além de manifestações hipocondríacas, Carmem trouxe também manifestações melancólicas associadas à sua imobilidade, uma identificação a um objeto morto e às intensas fantasias de destruição internas agregadas às suas dores e o temor de ter um tumor maligno em seu ventre. Poderíamos pensar então numa hipocondria melancólica?

Fine (1995) dedica-se a realizar uma revisão da hipocondria e sua relação com os vários quadros psicopatológicos, referindo-se a um "retorno à proximidade" desta afecção à melancolia, mencionando que Fédida (1972) “... insiste na proximidade entre a hipocondria e a melancolia". Pois além dos elementos já bem conhecidos desta última, coloca "a questão da relação entre dor corporal e dor psíquica na busca perpétua, no hipocondríaco, de um testemunho médico, na insatisfação ligada ao desmentido da saúde." Fine, ainda mencionando Fédida, acrescenta que a "... identificação ao órgão doente faria do hipocondríaco a "mãe da sua dor", como um "trabalho de gravidez", por uma identificação do 


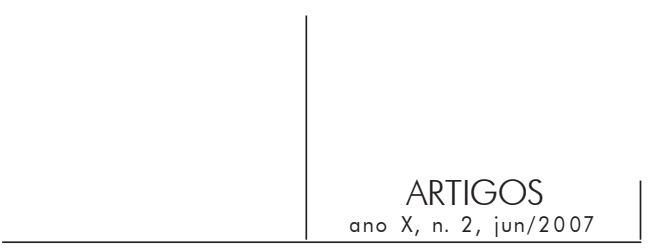

somático com o materno, que comporta um tipo de inversão do mito de retorno paradisíaco ao corpo da mãe e da revivescência de uma estada nele" (p. 8).

Deste modo, se a medicina atual despreza a função relevante da hipocondria, impede a condição de proporcionar uma passagem narrativa que possa resgatar aspectos do novo corpo que está "para nascer". Não existe, portanto, uma passagem "natural" e "prática" no climatério. Nem tampouco se exige do médico uma postura analítica, mas uma sensibilidade e uma atenção em relação a esta transição. A escuta médica deve estar livre da praticidade medicamentosa e precisa ser mediada pelo seu conhecimento do ser humano e do seu funcionamento somatopsíquico. O que se questiona aqui é em que medida os avanços na pesquisa dos hormônios, e seu funcionamento na mulher madura, podem ser equacionados com um saber e um cuidado de si, que parecem passar por elementos hipocondríacos relevantes para a elaboração de uma política erótica na maturidade.

\section{Referências}

Abraham, N. e Torok, M. A casca e o núcleo. São Paulo: Escuta, 1995.

Aisenstein, M. (1995). Entre psique e soma: a hipocondria. In: Aisenstein, M.; Fine, A. e Pragier, G. (org.). Hipocondria. São Paulo: Escuta, 2002.

ANDRÉ, S. (1986). O que quer uma mulher. Rio de Janeiro: Jorge Zahar, 1998.

Bueno, F. S. Dicionário da Língua Portuguesa. Rio de Janeiro: Fename, 1976.

CAmpolim, S. A menopausa. São Paulo: Publifolha, 2002 (Folha explica).

Fédida, P. (1995). O hipocondríaco médico. In: Aisenstein, M.; Fine, A. e Pragier, G. (org.). Hipocondria. São Paulo: Escuta, 2002.

Fine, A. (1995). Figuras psicanalíticas da hipocondria. In: Aisenstein, M.; Fine, A. e Pragier, G. (org.). Hipocondria. São Paulo: Escuta, 2002.

Freud, S. (1912). Tipos de desencadeamento da neurose. In: Edição Standard Brasileira das Obras Psicológicas Completas de Sigmund Freud. Rio de Janeiro: Imago, 1976. v. XII.

(1933). Novas conferências introdutórias à psicanálise. Conferência XXXIII:

Feminilidade. In: Edição Standard Brasileira das Obras Psicológicas Completas de Sigmund Freud. Rio de Janeiro: Imago, 1976. v. XXII.

Guedeney, C. e Weisbrot, C. (1995). A história da hipocondria. In: Aisenstein, M.; Fine, A. e Pragier, G. (org.). Hipocondria. São Paulo: Escuta, 2002.

Pragier, G. (1995). Questões metapsicológicas da hipocondria. In: Aisenstein, M.; Fine, A.; Pragier, G. (org.) Hipocondria. São Paulo: Escuta, 2002.

WiLde, O. Poemas em prosa e verso. Lisboa: Cavalo de Ferro, 2002. 


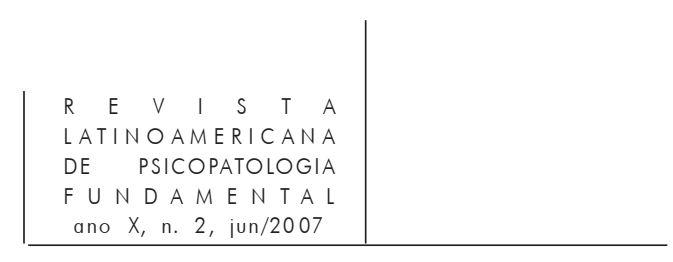

\section{Resumos}

Este texto enfoca las relaciones entre estados hipocondríacos e melancólicos existentes en el paso de la madurez femenina, es decir, en el período del climaterio y de la menopausia, atravesado por la perdida radical de la capacidad biológica de procreación. Va resaltar el pathos femenino en esta etapa y la necesidad de la mujer establecer una nueva política erótica que surge de su cuerpo en transición, por medio de la reedición preedípica y edípica, vivida a partir de la regresión y de la transferencia en el proceso analítico.

Palabras claves: Psicoanálisis, hipocondría, melancolía, erotismo, menopausia

Ce texte se concentre sur les rapports entre les états hypocondriaques et mélancoliques que l'on retrouve dans le passage de la maturité féminine, c'est-à-dire, pendant la période du climatère et de la ménopause, marquées par la perte radicale de la capacité biologique de la procréation. Nous relevons le pathos féminin dans cette étape et la nécessité de la femme d'établir une nouvelle politique érotique qui surgit de son corps en transition à travers la réédition pré-oedipique et oedipique vécue à partir de la régression et du transfert dans le processus analytique.

Mots clés: Psychanalyse, hypocondrie, mélancolie, érotisme, ménopause

This article focuses on the relationships between present-day hypochondria and melancholic states in the passage women to maturity. That is, in the period of the climacteric and the menopause, evidenced by the radical loss of the biological ability to procreate. It discusses women's pathos in this stage and their need to establish a new erotic politics that springs from their body in transition, by going through the prior and subsequent oedipical stages, experienced in regression and transference in the analytic process.

Key words: Psychoanalysis, hyponchondria, melancholy, erotism, menopause

Versão inicial recebida em janeiro de 2007

Versão revisada recebida em maio de 2007 